\title{
Evidence for the Suprasubduction Origin of Mantle Section Rocks of Voykar Ophiolite, Polar Urals
}

\author{
I. A. Belousov, V. G. Batanova, G. N. Savelieva, \\ and Corresponding Member of RAS A. V. Sobolev \\ Received June 8, 2009
}

DOI: $10.1134 / \mathrm{S} 1028334 \mathrm{X} 09080340$

Reconstruction of geodynamic environments of formation of mantle section rocks of ophiolite complexes is an important problem in geology. Solution of this problem cannot be a simple consequence of reconstruction of environment of formation of crustal parts of ophiolite sequences because of their possible tectonic combination with the mantle basement. Analysis of concentrations of incompatible trace elements in clinopyroxene and/or amphibole from mantle section rocks is a direct method to establish their origin. Such an approach allows us to estimate the geochemical peculiarities of mantle melts migrating through peridotites and determine the geodynamic environments of their formation. The first data on the composition of clinopyroxene and amphibole from pyroxenite veins from the mantle section of Voykar ophiolite, Polar Urals, proving their suprasubduction origin are reported in this paper.

Voykar ophiolite forms a part of the largest belt of mafic-ultramafic rocks in the world with a length of $\sim 400 \mathrm{~km}$ [1]. The ophiolite has been well studied: its internal structure is deciphered and characteristics of composing rocks were published. Ophiolitic sequences rocks of the Polar Urals are considered as giant fragments of mantle and oceanic crust formed in backarc marginal basins under suprasubduction environments [1-3]. Attribution to suprasubduction environment was proved for plagiogranites $[1,4]$, as well as for the rocks of layered and dyke complexes of Voykar ophiolite [6]. However, $\mathrm{Nd}-\mathrm{Sm}$ isotopic data obtained for harzburgite, dunite, and pyroxenite veins from mantle section of Voykar Ophiolite suggested their formation from the mantle with the composition of a mid-ocean

Vernadsky Institute of Geochemistry and Analytical Chemistry, Russian Academy of Sciences, Moscow Geological Institute, Russian Academy of Sciences, Moscow Max-Plank Institut für Chemie, Mainz, Germany ridge basalt (MORB) source [7]. Our new data allows us to make another conclusion.

We studied mantle rocks in the northern part of the ophiolite where the thickness of peridotite sections reaches $6 \mathrm{~km}$. Harzburgite depleted to a variable degree in basaltic material predominates among the rocks. Dunite makes up about $20 \%$ of periodtites and represents pathways, along which mantle melts migrated during the ascent of host harzburgite under the influence of stress [3]. Pyroxenite veins associate with dunite in space. Dunite and pyroxenite were formed within the harzburgite section on the final stage of magmatic evolution of mantle section [3]. Pyroxenites were studied in detail and sampled in the area between two rivers Khoila-Left Paiera and Lagorta.

Morphology and thickness of pyroxenite veins are rather diverse. The earliest pyroxenite generations cutting dunite are presented by veins of diopside-enstatite composition with a thickness from $1-2$ to $50 \mathrm{~cm}$. Thin diopsidite veins are abundant in dunite, and sometimes they replace dunite veins along the strike. Zoned veins of dark green websterite are the latest. Veins of giant-granular pyroxenite with a thickness of $0.5-2.5 \mathrm{~m}$ form swarms traced for a distance of up to $3 \mathrm{~km}$ from a large dunite body. Most of the rocks are characterized by coarse-granular and giant-granular textures and have reaction contacts with host harzburgite. The modal composition of the rocks varies significantly. Magmatic high-aluminum amphibole (Amf) occurs in many pyroxenites in addition to clino- and orthopyroxenes (Cpx, Opx).

Compositions of Cpx and Amf were analyzed at the Max-Plank-Institut für Chemie. Concentrations of major elements were measured with the electron microanalyzer Jeol Jxa-8200. Concentrations of trace elements were measured by the LA ICP-MS method on the Thermo Finnigan Element 2 apparatus with New Wave UP213 laser adaptor. The diameter of the laser beam was $80 \mu \mathrm{m}$. Helium was used as a transport- 
Representative analysis of amphibole and clinopyroxene from pyroxenite of the mantle section of the Voykar ophiolite

\begin{tabular}{|c|c|c|c|c|c|c|c|c|c|c|}
\hline \multirow{3}{*}{$\begin{array}{c}\text { Compo- } \\
\text { nent }\end{array}$} & pu07 4/3 & pu07 10/2 & pu07 30 & pu07 31/3 & pu07 55/10 & pu07 33/1 & pu07 10/2 & pu07 55/10 & $K_{d} \mathrm{Amf} / 1$ & $K_{d} \mathrm{Cpx} / \mathrm{l}$ \\
\hline & Cpxt & Web & Web & Web & Web & Web & Web & Web & & \\
\hline & Amf & Amf & $\mathrm{Amf}$ & Amf & $\mathrm{Amf}$ & Amf & $\mathrm{Cpx}$ & $\mathrm{Cpx}$ & & \\
\hline$\overline{\mathrm{SiO}_{2}}$ & 48.53 & 46.31 & 46.23 & 47.42 & 49.74 & 49.57 & 52.18 & 53.05 & & \\
\hline $\mathrm{Na}_{2} \mathrm{O}$ & 1.46 & 1.90 & 1.52 & 1.69 & 0.94 & 1.55 & 0.26 & 0.08 & & \\
\hline $\mathrm{CaO}$ & 12.60 & 12.43 & 12.01 & 11.91 & 13.22 & 12.02 & 23.60 & 23.97 & & \\
\hline $\mathrm{K}_{2} \mathrm{O}$ & 0.06 & 0.07 & 0.18 & 0.19 & 0.04 & 0.15 & BDL & BDL & & \\
\hline $\mathrm{FeO}$ & 5.64 & 4.90 & 4.57 & 4.57 & 3.72 & 4.09 & 3.00 & 2.64 & & \\
\hline $\mathrm{MgO}$ & 18.51 & 17.83 & 18.18 & 18.93 & 18.91 & 19.69 & 16.36 & 16.91 & & \\
\hline $\mathrm{Al}_{2} \mathrm{O}_{3}$ & 9.88 & 11.67 & 13.93 & 12.14 & 10.22 & 9.02 & 2.99 & 3.01 & & \\
\hline $\mathrm{TiO}_{2}$ & 0.33 & 0.54 & 0.23 & 0.11 & 0.18 & 0.10 & 0.18 & 0.07 & & \\
\hline $\mathrm{Cr}_{2} \mathrm{O}_{3}$ & 0.37 & 1.89 & 0.42 & 0.21 & 0.87 & 0.37 & 0.98 & 0.36 & & \\
\hline $\mathrm{MnO}$ & 0.07 & 0.07 & 0.07 & 0.08 & 0.04 & 0.08 & 0.09 & 0.08 & & \\
\hline $\mathrm{NiO}$ & 0.10 & 0.07 & 0.13 & 0.10 & 0.11 & 0.09 & 0.03 & 0.05 & & \\
\hline Total & 97.54 & 97.66 & 97.46 & 97.36 & 97.99 & 96.64 & 99.67 & 100.22 & & \\
\hline $\mathrm{Mg}^{\#}$ & 85.40 & 86.64 & 87.64 & 88.08 & 90.06 & 89.57 & 90.67 & 91.95 & & \\
\hline $\mathrm{Rb}$ & 1.42 & 2.15 & 0.74 & 0.80 & 0.59 & 0.78 & 0.016 & BDL & 0.14 & \\
\hline $\mathrm{Ba}$ & 12.65 & 20.47 & 2.80 & 2.23 & 0.59 & 3.77 & 0.94 & “ & 0.23 & \\
\hline $\mathrm{Nb}$ & 0.034 & 0.048 & 0.018 & 0.025 & 0.020 & 0.031 & 0.007 & “ & 0.3 & \\
\hline $\mathrm{La}$ & 0.45 & 0.56 & 0.005 & 0.005 & BDL & 0.018 & 0.102 & “ & 0.2 & 0.032 \\
\hline $\mathrm{Pb}$ & 0.15 & 0.42 & 0.41 & 0.38 & 0.12 & 0.57 & 0.087 & 0.027 & 0.15 & 0.01 \\
\hline $\mathrm{Ce}$ & 1.97 & 2.63 & 0.024 & 0.027 & 0.014 & 0.072 & 0.54 & 0.006 & 0.4 & 0.057 \\
\hline $\mathrm{Sr}$ & 48.56 & 44.28 & 5.14 & 3.20 & 2.68 & 6.32 & 12.38 & 0.74 & 0.3 & 0.082 \\
\hline $\operatorname{Pr}$ & 0.42 & 0.62 & 0.006 & 0.008 & 0.005 & 0.015 & 0.126 & BDL & 0.277 & 0.1 \\
\hline $\mathrm{Nd}$ & 2.74 & 4.02 & 0.073 & 0.068 & 0.067 & 0.099 & 0.817 & 0.021 & 0.8 & 0.129 \\
\hline $\mathrm{Zr}$ & 7.79 & 8.38 & 0.24 & 0.28 & 0.25 & 0.60 & 2.45 & 0.08 & 0.4 & 0.046 \\
\hline $\mathrm{Hf}$ & 0.33 & 0.30 & 0.019 & 0.020 & 0.028 & 0.030 & 0.106 & BDL & 0.7 & \\
\hline $\mathrm{Sm}$ & 1.23 & 1.89 & 0.065 & 0.048 & 0.115 & 0.067 & 0.403 & 0.032 & 1.7 & 0.211 \\
\hline $\mathrm{Eu}$ & 0.41 & 0.79 & 0.033 & 0.022 & 0.043 & 0.027 & 0.172 & 0.018 & 1.3 & 0.35 \\
\hline $\mathrm{Gd}$ & 1.62 & 2.82 & 0.23 & 0.14 & 0.37 & 0.17 & 0.63 & 0.14 & 1.7 & 0.3 \\
\hline $\mathrm{Ti}$ & 1824 & 3283 & 1326 & 670 & 1099 & 615 & 989 & 336 & 2.94 & 0.229 \\
\hline $\mathrm{Tb}$ & 0.27 & 0.49 & 0.069 & 0.040 & 0.117 & 0.046 & 0.117 & 0.040 & 2 & 0.3 \\
\hline Dy & 1.77 & 3.47 & 0.75 & 0.41 & 1.11 & 0.45 & 0.82 & 0.36 & 2 & 0.256 \\
\hline Ho & 0.35 & 0.73 & 0.23 & 0.12 & 0.32 & 0.13 & 0.18 & 0.09 & 2 & 0.25 \\
\hline Y & 10.04 & 20.73 & 6.07 & 3.47 & 8.59 & 3.46 & 4.47 & 2.26 & 2.3 & 0.245 \\
\hline $\mathrm{Er}$ & 1.10 & 2.27 & 0.85 & 0.47 & 1.15 & 0.48 & 0.50 & 0.30 & 2.12 & 0.259 \\
\hline $\mathrm{Tm}$ & 0.15 & 0.30 & 0.15 & 0.09 & 0.18 & 0.08 & 0.07 & 0.05 & 2 & 0.25 \\
\hline $\mathrm{Yb}$ & 1.08 & 1.97 & 1.14 & 0.73 & 1.43 & 0.65 & 0.42 & 0.35 & 1.63 & 0.214 \\
\hline $\mathrm{Lu}$ & 0.17 & 0.30 & 0.19 & 0.12 & 0.23 & 0.11 & 0.06 & 0.06 & 1.5 & 0.2 \\
\hline
\end{tabular}

Note: Cpxt is clinopyroxenite; web is websterite; Amf is amphibole; Cpx is clinopyroxene; $K_{d}$ Amf/l are partitioning coefficients between amphibole and the melt; $K_{d} \mathrm{Cpx} / 1$ are partitioning coefficients between clinopyroxene and the melt. The concentrations of major components are given in wt \%; the concentrations of trace elements are in ppm. BDL is below detection limits. 


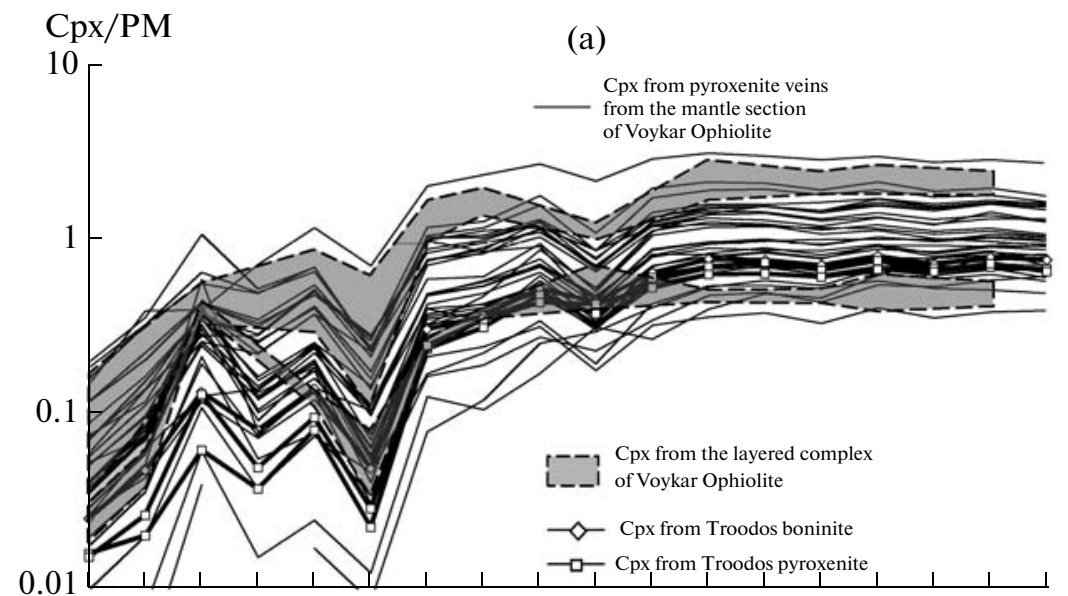

La Ce Sr Pr Nd Zr Sm Eu Gd Ti Tb Dy Ho Y Er Tm Yb Lu
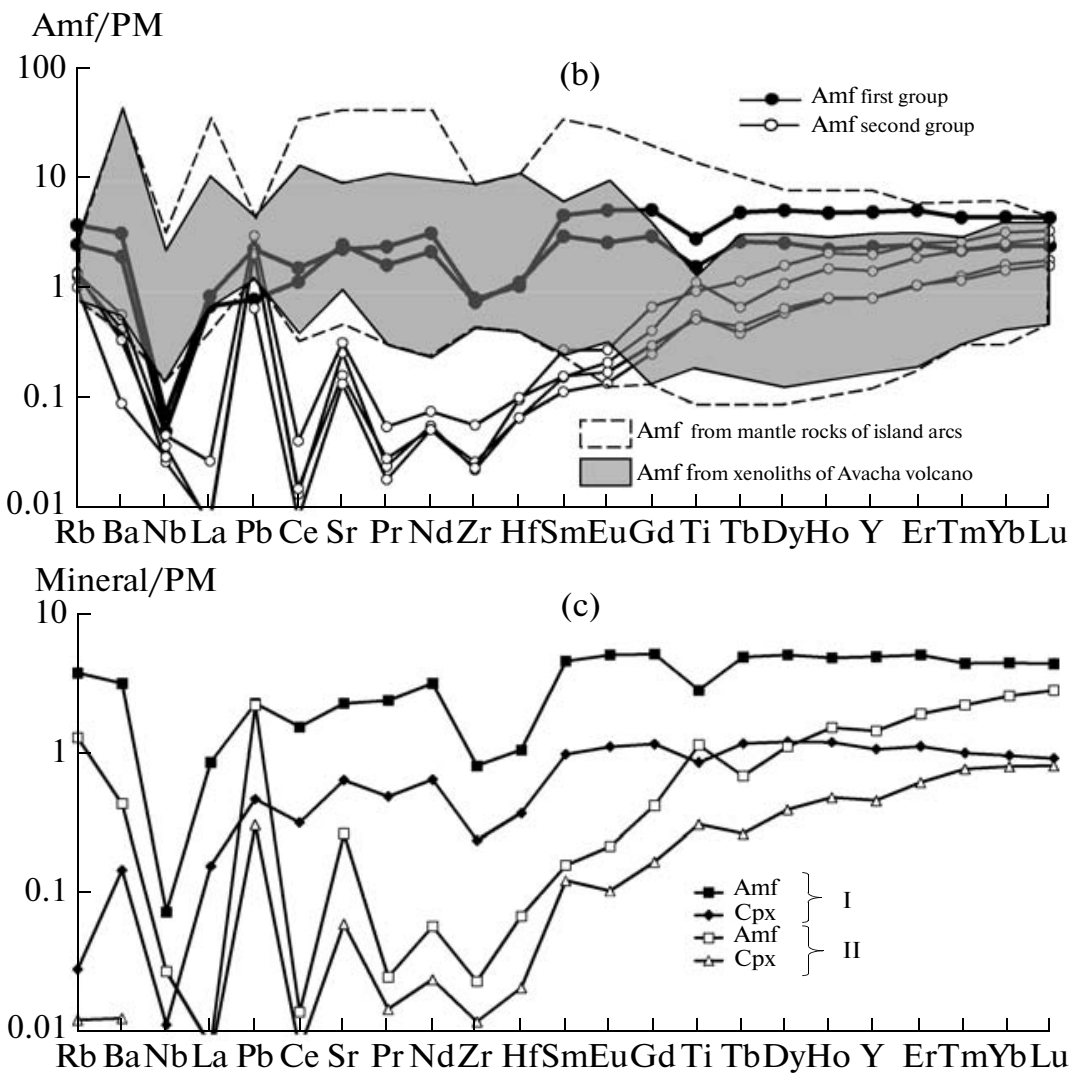

Fig. 1. Distribution pattern of trace elements normalized to the composition of primitive mantle (PM) [5] for clinopyroxenes (a) and amphiboles (b) from pyroxenite veins of the mantle section of the Voykar ophiolite and comparison of compositions of clinopyroxene and amphibole from one sample (c). For comparison, (a) the compositions of clinopyroxenes from boninite and pyroxenite of the mantle section of Troodos ophiolites and fields of clinopyroxene composition from the layered complex of the Voykar ophiolite [6]; (b) field of amphibole compositions from xenoliths of Avacha volcano [10] and the field of all published compositions of amphiboles from mantle rocks from island arcs (http://georoc.mpch-mainz.gwdg.de/georoc/).

ing gas from the laser adaptor to the mass spectrometer. Background analysis proceeded for $20 \mathrm{~s}$, and sample analysis for 80-100 s. KL2-G and NIST 612 glasses were used as standards [8].

The clinopyroxene composition corresponds to diopside (wt \%): $\mathrm{CaO} 22-24.5 ; \mathrm{Al}_{2} \mathrm{O}_{3} 1.0-4.5 ; \mathrm{Cr}_{2} \mathrm{O}_{3}$
$0.1-1.3 ; \mathrm{Mg} \#\left(100 * \mathrm{Mg} /\left(\mathrm{Mg}+\mathrm{Fe}^{2+}\right)\right.$ 86-95) (Table 1$)$. Contents of trace elements demonstrate a wide range of Cpx compositions from different veins (Table 1, Fig. 1a). Pattern of the distribution of incompatible elements are subparallel and characterized by high concentrations of light rare-earth elements (LREE) 

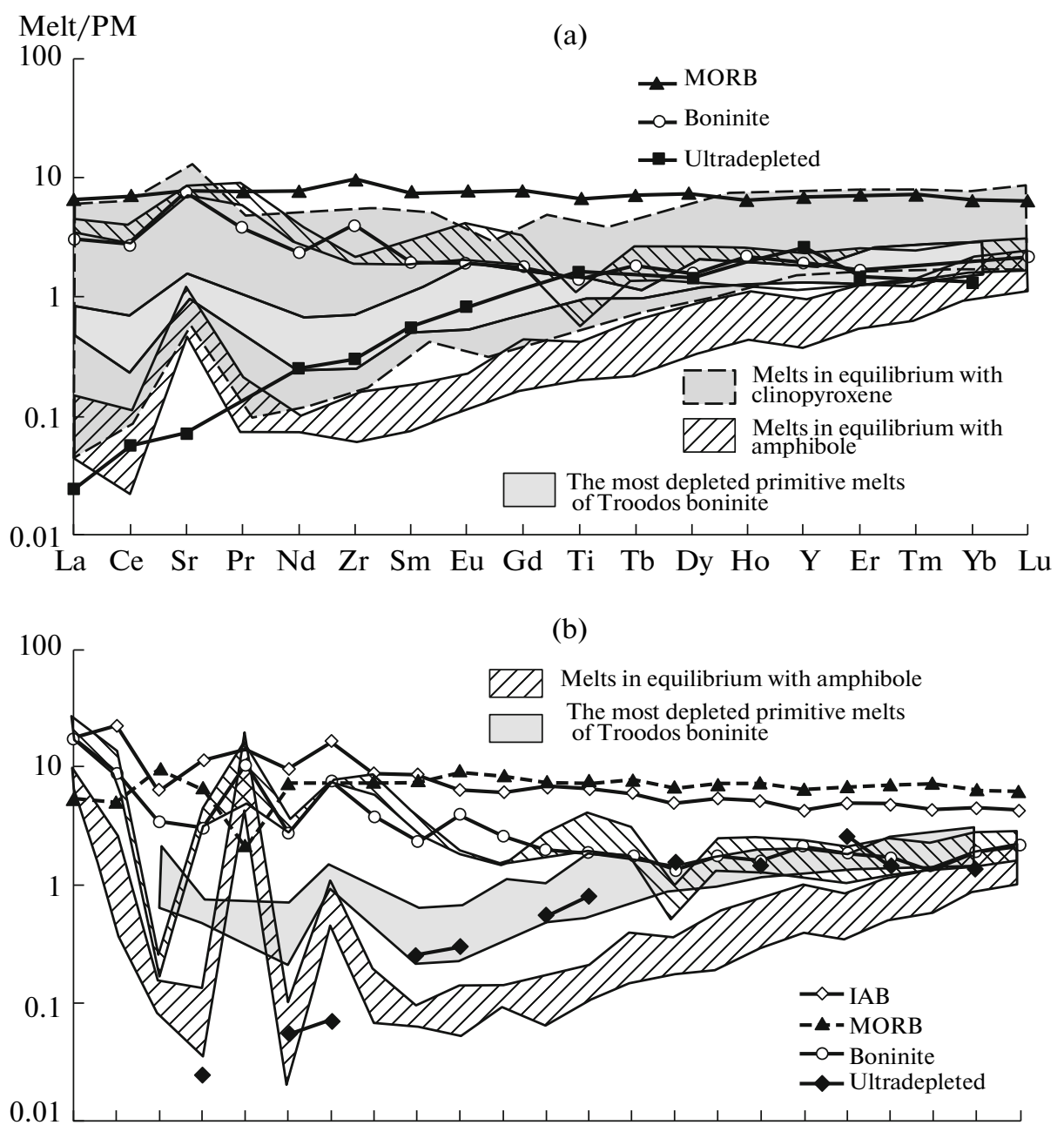

$\mathrm{Rb} \mathrm{Ba} \mathrm{Nb} \mathrm{La} \mathrm{Pb} \mathrm{Ce}$ Sr Pr Nd Zr Hf Sm EuGd Ti Tb DyHo Y Er Tm Yb Lu

Fig. 2. Calculated concentrations of trace elements normalized to the composition of the primitive mantle [5] in melts in equilibrium with clinopyroxenes (a) and amphiboles (b) from pyroxenite veins of the mantle section of Voykar ophiolite. Average compositions of MORB, island arc basalt, and boninite [14], as well as the composition of ultradepleted melt inclusion [15], and the field of the most depleted primitive melts of high-calcium boninite from Troodos [9] are plotted for comparison.

and $\mathrm{Sr}$ at relatively low concentrations of heavy REE. Similar pattern of the distribution of incompatible elements are typical for Cpx phenocrysts from boninite of upper pillow lavas and from pyroxenite veins of the Troodos ophiolite (Cyprus), which represents a typical example of ophiolite formed above the subduction zone [9]. The range of Cpx composition from pyroxenite completely overlaps that for $\mathrm{Cpx}$ from the layered complex rocks [6] (Fig. 1a).

Compositions of amphiboles correspond to hightemperature pargasite $\left(\sim 10-12 \mathrm{wt} \% \mathrm{Al}_{2} \mathrm{O}_{3}\right)$ (Table 1$)$. The presence of magmatic Amf provides evidence for an increased water content in the melt (fluid). The concentration of incompatible trace elements allows us to distinguish two groups of Amf (Fig. 1b). Amf of the first group demonstrates compositions typical for amphiboles from subduction zones [10]. Amf of the second group are strongly depleted in middle and light REE relatively to the first group. Amf of both groups are strongly enriched in large-ion lithophile elements (LILE), namely $\mathrm{Rb}, \mathrm{Ba}$, and $\mathrm{Sr}$, in comparison with high field strength elements (HFSE), namely $\mathrm{Nb}$ and $\mathrm{Zr}$. In addition, Amf of the second group is characterized by pronounced $\mathrm{Pb}$ anomaly relatively to $\mathrm{La}$ and Ce. As illustrated in Fig. 1c, pattern of the distribution of incompatible trace elements for Amf and Cpx from the same sample are parallel to each other for all elements (first group) or for the elements to the right from $\mathrm{Ce}$ (second group); their concentrations in Amf are 3-5 times higher than those in Cpx. The parallel character of distribution pattern for incompatible elements in coexisting Cpx and Amf provides evidence for the fact that these minerals are in equilibrium and their final formation from the melt was simultaneous. 
We calculated the compositions of melts in equilibrium with Amf and Cpx on the basis of partitioning coefficients $\left(K_{d}\right)$ between the mineral and the melt. $K_{d}$ obtained for Troodos boninite were applied for $\mathrm{Cpx}$ (Table 1) [11]. Reactive relations between harzburgite and pyroxenite veins provide evidence for increased $\mathrm{SiO}_{2}$ concentration in the melt [12]. Because of this, we used the $K_{d} \mathrm{Amf} / \mathrm{melt}$ for the following conditions: $\mathrm{SiO}_{2}$ content in the melt $55-65$ wt $\% ; P=1.5 \mathrm{GPa}$; $T=1000^{\circ} \mathrm{C}[13]$.

Fields of estimated melt compositions are demonstrated in Fig. 2. Melts calculated on the basis of Cpx (Fig. 2a) form a wide field of parallel pattern; the uppermost of them are characterized by a high Sr concentration and low contents of middle REE and HFSE in comparison with MORB [14]. The varieties located in the lowermost part of the field are more depleted in middle and heavy REE than ultradepleted melts formed at $17 \%$ of mantle MORB melting [15]. At the same time, they demonstrate enrichment in light REE and Sr relatively to the latter. The entire spectrum of melt compositions could be formed by progressive melting of the depleted mantle source caused by the influx of the fluid component enriched in LILE and, to a smaller degree, light REE.

Melts calculated on the basis of Amf compositions form two groups (Fig. 2). Distribution pattern of both groups of trace elements normalized to the composition of the primitive mantle have a clear $\mathrm{Nb}$ minimum and $\mathrm{Pb}$ maximum (Fig. 2b). The first group of compositions corresponds to melts of boninite composition [14]. The second group is ultradepleted in light and middle REEs, but is characterized by significant enrichment in $\mathrm{Rb}, \mathrm{Ba}, \mathrm{Sr}$, and $\mathrm{Pb}$. According to character of the distribution pattern, these melts are close to the group of the most depleted from primitive melts of high-calcium boninite from Troodos [9].

It is remarkable that two groups of melt compositions in equilibrium with $\mathrm{Cpx}$ from rocks of the layered complex of the Voykar ophiolite [6] fit into the field of the studied melts, which has cast doubt on the conclusions of the authors about the formation of these groups in different geodynamic settings.

Thus, melts participated in pyroxenite formation have concentrations of incompatible elements indicating their formation during progressive melting of the mantle wedge above the subduction zone. Conse- quently, the mantle section of the Voykar ophiolite may represent the upper parts of the mantle above the subduction zone.

\section{ACKNOWLEDGMENTS}

This work was supported by the Russian Foundation for Basic Research (project nos. 09-05-01165, 0905-01193, and 08-05-00151) and the President of the Russian Federation (grant NSh-150.2008.5).

\section{REFERENCES}

1. G. N. Savel'eva, Gabbro-Ultrabasitic Complexes of Ophiolites of Urals and Their Analogues in Modern Oceanic Crust (Nauka, Moscow, 1987) [in Russian].

2. N. L. Dobretsov, Yu. E. Moldovantsev, A. P. Kodak, et al., Petrology and Metamorphism of Ancient Ophiolites as Exemplified by Polar Urals and Western Sayan (Nauka, Novosibirsk, 1977) [in Russian].

3. G. N. Saveleva, A. V. Sobolev, V. G. Batanova, et al., Geotectonics 42 (6), 430-449 (2008) [Geotektonika, No. 6, 1-12 (2008)].

4. A. A. Savelev, Geotectonics 30 (3), 190-201 (1996) [Geotektonika, No. 3, 25-35 (1996)].

5. A. W. Hofmann, Earth Planet. Sci. Lett. 90, 297-314 (1988) .

6. A. N. Pertsev, G. N. Savelieva, and S. G. Simakin, Ofioliti, No. 28, 33-41 (2003).

7. M. Sharma, G. J. Wasserburg, D. A. Papanastassiou, et al., Earth Planet. Sci. Lett. 135, 101-114 (1995).

8. K. P. Jochum, D. B. Dingwell, A. Rocholl, et al., Geostandards Newslet. J. Geostandards and Geoanal 24 (1), 87-133 (2000).

9. A. V. Sobolev, M. V. Portnyagin, L. V. Dmitriev, et al., Petrologiya 1 (4), 379-412 (1993).

10. S. Ishimaru and S. Arai, in: Metasomatism in Oceanic and Continental Lithospheric Mantle (London: Geol. Soc. Spec. publ., 2008), pp. 35-55.

11. A. V. Sobolev, A. A. Migdisov, and M. V. Portnyagin, Petrology 4 (3), 307-319 (1996) [Petrologiya 4 (3), 326-336 (1996)].

12. A. V. Sobolev, A. W. Hofmann, S. V. Sobolev, et al., Nature 434 (7033), 590-597 (2005).

13. M. Tiepolo, R. Oberti, A. Zanetti, et al., Rev. Miner. Geochem. 67, 417-452 (2007).

14. P. Kelemen, K. Hanghoi, and A.R. Green, in: Treatise on Geochemistry (Amsterdam: Elsevier, 2004), pp. 593659.

15. A. V. Sobolev and N. Shimizu, Dokl. Akad. Nauk 326 (3), 354-360 (1992). 